\title{
Analysis of the Performance of The Four-Blade Darrieus Wind Turbine at the Jamik Bukit Asam Mosque Complex Tanjung Enim South Sumatra
}

\author{
Mustafa Kamal $^{1,2}$, Fatahul Arifin ${ }^{1,3}$, Rusdianasari ${ }^{1}$ \\ ${ }^{1}$ Department of Renewable Energy Engineering, Politeknik Negeri Sriwijaya, Palembang, Indonesia \\ ${ }^{2}$ Corporate Social Responsibility (CRS), PT. Bukit Asam Tbk Tanjung Enim, Indonesia \\ ${ }^{3}$ Department of Mechanical Engineering, Politeknik Negeri Sriwijaya, Palembang, Indonesia
}

\begin{tabular}{l}
\hline \hline Article Info \\
\hline Article history: \\
Received July 11, 2021 \\
Revised August 10, 2021 \\
Accepted August 20, 2021
\end{tabular}

\section{Keywords:}

Renewable Energy

Wind Energy

Wind Speed

Wind Turbine

Darrieus Turbine

\begin{abstract}
Several types of renewable energy have been developed, such as solar energy, biomass, hydro energy, geothermal, and wind energy. Wind energy is an up-and-coming alternative and renewable energy. Wind energy is more environmentally friendly than available energy sources and has more accessible operational and maintenance costs. Indonesia has a relatively small natural wind energy potential because the wind speed in Indonesia is on average 3-6 m/s due to its location. Geographically, it is located in the equatorial area, especially the Muara Enim area, South Sumatra. This study aims to design a prototype the four-blade darrieus type vertical axis wind turbine (VAWT) needed for the utilization of wind energy which is used for Coffee Shop electricity needs at the Jamik Bukit Asam Tanjung Enim Mosque complex, South Sumatra, with the conclusion that the wind turbine, wind turbine rotation, the magnitude of the output voltage and The current generated significantly affects the wind speed in the area.
\end{abstract}

This is an open access article under the CC BY-SA license.

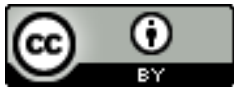

\section{Corresponding Author:}

Fatahul Arifin,

Departement of Mechanical Engineering,

Politeknik Negeri Sriwijaya

Jalan Srijaya Negara Bukit Besar Palembang, Sumatera Selatan, 30139, Indonesia

Email: farifinus@polsri.ac.id; farifinus@yahoo.com

\section{INTRODUCTION}

One of the rapidly growing renewable energies in the world today is wind energy [1]. Wind energy has long been known and used by humans, for example, for power generation, but wind energy in the Indonesian region is classified as low wind speed. However, wind potential in Indonesia is available almost all year round, making it possible to develop small-scale power generation systems [2]. One of them is the manufacture of wind turbines, which will later help generate electricity and meet the community's electricity needs [3].

Energy has an essential role in developing a country if its availability and development are hand in hand and support national development [4][20]-[23]. The need for energy, especially electrical energy in Indonesia, is an inseparable part of the needs of people's daily lives, along with the rapid development in the fields of technology, industry and information. According to PT Perusahaan Listrik Negara, the number of customers during 2009-2013 increased from 39.9 million to 53.7 million or an average of 3 million annually (RUPTL 2015-2025) [5][13][14][16].

The availability of energy is not commensurate with the increasing demand, so renewable energy is needed to minimize the use of fossil energy. Renewable energy sources are expected to have an active role in 
the present and future energy diversification scenario [6][24]. Wind energy is renewable energy [6]. In most areas, the quality and quantity of wind have low speed where wind energy engineering is needed because of its significant and efficient potential in the future [7][25]. According to the latest Global Wind Report, the total global wind power installation was $318.105 \mathrm{GW}$ at the end of 2013 [8][17][18].

Indonesia has a relatively small potential for wind energy naturally due to the average wind speed in Indonesia being 3-6 m/s due to its geographical location, which is located in the equator. However, some areas are wind areas due to the narrowing between two islands or the mountain slope area between two adjacent mountains, especially in the Muara Enim area, South Sumatra [9].

Effective technology is needed to increase the possibility of using wind energy at low wind speeds [10]. Therefore, it is necessary to develop a type of wind turbine suitable for use in areas with low wind speeds. Discussion on the use of low-speed wind is also considered necessary because it can increase Indonesia's electrification ratio. A prototype 4-blade vertical wind power plant based on Internet of Things (IoT) technology with a hybrid power system has been designed to optimize wind energy utilization in lowspeed wind conditions. The utilization of IoT technology in hybrid power systems provides many advantages, namely controlling, monitoring, recording data, and analyzing to ensure efficient and optimal power delivery [11].

Wind turbines with an axis perpendicular to the wind direction have many modification options to optimize the extraction of the kinetic energy of the fluid flowing through it. Modification of the rotor blades is one option to optimize energy extraction carried out by a Vertical Axis Wind Turbine (VAWT) [12][15][19]. In this research, a study with turbine analysis with four blades Type Darrieus was conducted for the coffee shop electricity needs in the Jamik Bukit Asam Mosque complex, Tanjung Enim, South Sumatra.

\section{RESEARCH DESIGN}

The design of this research uses a Darrieus type $\mathrm{H}$ type vertical axis wind turbine with four blades as shown in Figure 1, which serves to capture the wind in converting mechanical energy into kinetic energy, which is connected to each FA 300 permanent magnet generator which has a maximum power of $3000 \mathrm{~W}$ with $24 \mathrm{~V}$ current-voltage and generates Alternating Current (AC).

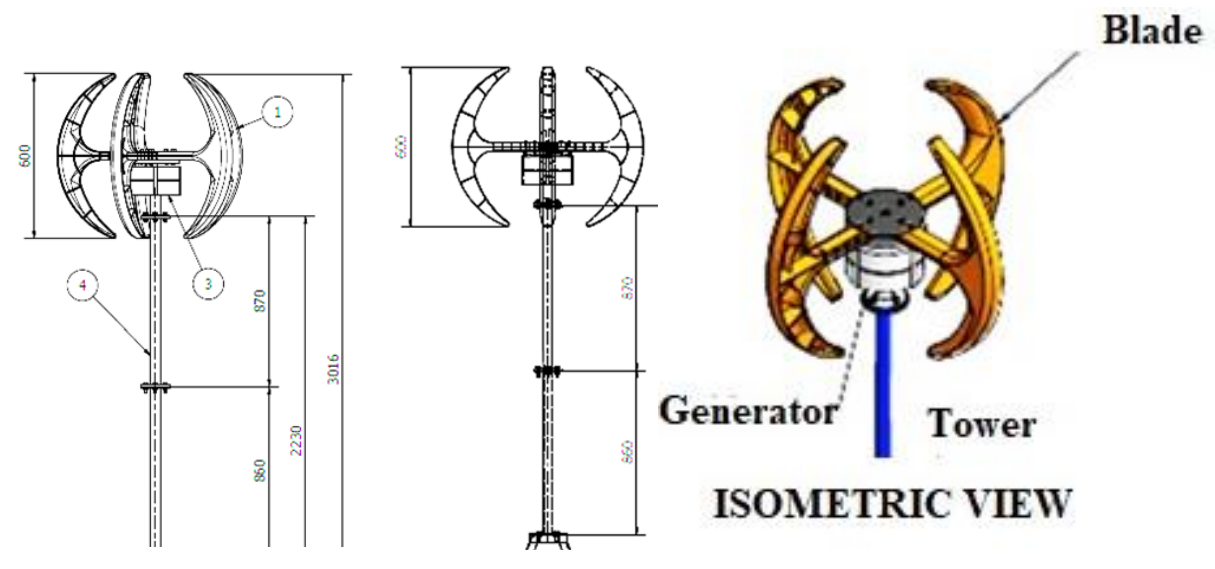

Figure 1. Vertical Axis Wind Turbine (VAWT) design

Actual conditions conducted this research. The turbine is installed in the tower building at the Jamik Bukit Asam Mosque tower, Tanjung Enim, as shown in Figure 2. Because the building uses a tower, it is possible to change the installation height. The material used in the blades is nylon fibre with a blade length of $600 \mathrm{~mm}$ and a wheel diameter of $900 \mathrm{~mm}$. The turbine blades are connected to the rotor using galvanized pipe material with a diameter of $20 \mathrm{~mm}$ and a mild steel plate with a thickness of $2 \mathrm{~mm}$. In this tower construction, generator sets, measuring instruments, panel boxes, lights, proximity sensors and electrical installations will be placed. 


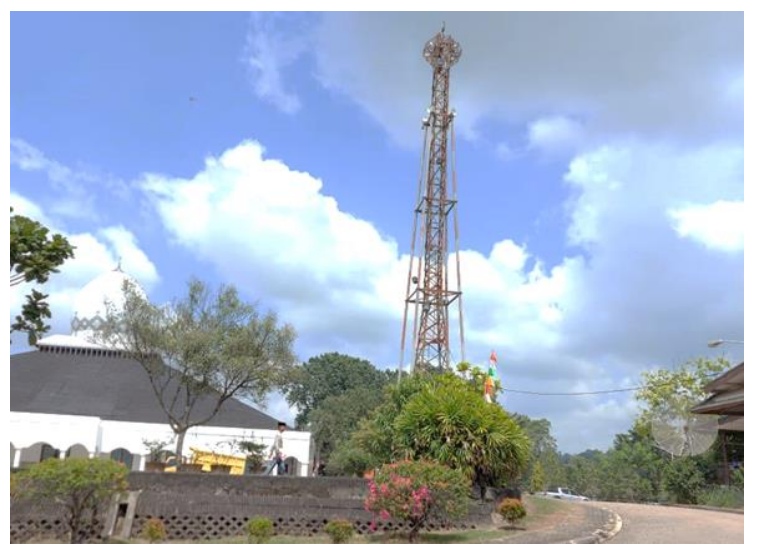

Figure 2. Location of Darrieus wind turbine installation at Jamik Bukit Asam mosque, Tanjung Enim

The research design used in collecting data is shown in Figure 3. Namely, the output of the wind generator is measured by voltage and current metering. Furthermore, the wind generator output is converted from Alternating Current (AC) to Direct Current (DC) through the wind charge controller and then supplies the battery and LED lights. The voltage and current of the LED lamp are measured using a meter. RPM on the wind generator is measured using a proximity sensor that reads the rotation of the wind generator. Voltage and current metering data used to measure wind generator output and load and RPM data from proximity produce RS 485 Modbus communication data. They will be converted to TCP/IP Modbus communication data to retrieve the data in real-time and stored in a database that will then be processed as test data.

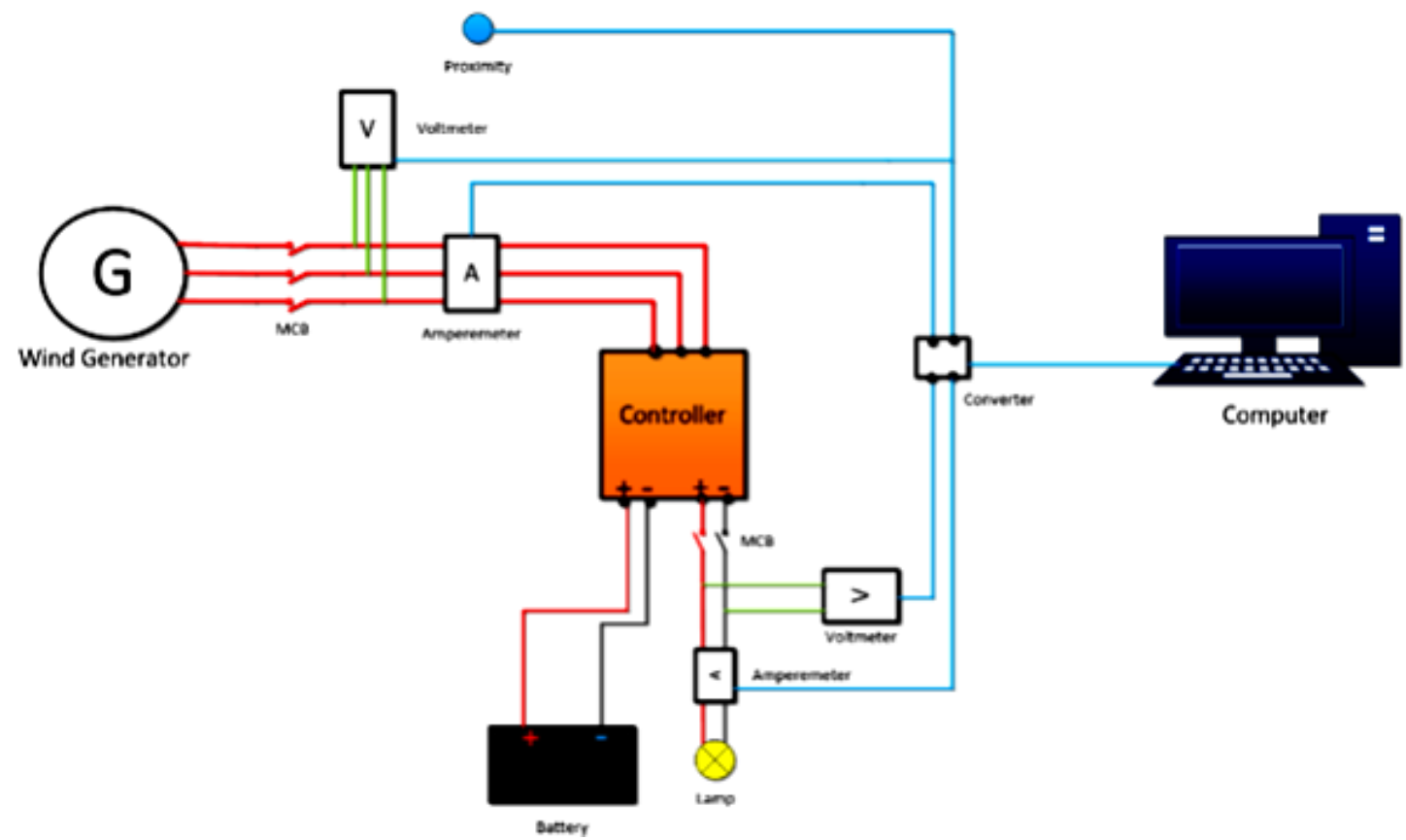

Figure 3. Electrical system

\section{RESULTS AND DISCUSSION}

This study takes data and writes research results in a tabular form with the format shown in Table 1. The table format will be used in the daily data collection starting at 09.00 WIB until 16.00 WIB with time intervals every 30 minutes within three days of testing. in the Jamik Bukit Asam Mosque area. 
Table 1. Measurement wind data in the Jamik Bukit Asam mosque area

\begin{tabular}{|c|c|c|c|c|c|}
\hline \multicolumn{6}{|c|}{ Data taken on June 19, 2021 - Day 1} \\
\hline \multirow[b]{2}{*}{ Time } & \multirow[b]{2}{*}{ Wind Speed $(\mathbf{m} / \mathbf{s})$} & \multicolumn{4}{|c|}{ Curved H Type 4 Blade Darrieus Vertical Wind Turbine } \\
\hline & & Output Voltage (V) & Rate (A) & $\begin{array}{l}\text { Turbine Rotational } \\
\text { Speed (rpm) }\end{array}$ & $\begin{array}{l}\text { Power Load } \\
\text { (Watt) }\end{array}$ \\
\hline 09:00 & 1,21 & 1,9 & 0 & 96,77 & 0,000 \\
\hline 09:30 & 1,44 & 1,81 & 0 & 115,38 & 0,000 \\
\hline 10:00 & 2,88 & 1,66 & 0 & 230,76 & 0,000 \\
\hline $10: 30$ & 1,60 & 1,56 & 0 & 127,65 & 0,000 \\
\hline 11:00 & 1,53 & 1,46 & 0 & 122,44 & 0,000 \\
\hline $11: 30$ & 1,50 & 1,37 & 0 & 120 & 0,000 \\
\hline 12:00 & 6,00 & 8,13 & 5,4 & 120 & 43,902 \\
\hline $12: 30$ & 4,95 & 5,69 & 0 & 115,38 & 0,000 \\
\hline 13:00 & 1,47 & 4,1 & 0 & 117,64 & 0,000 \\
\hline $13: 30$ & 4,90 & 3,34 & 0 & 111,11 & 0,000 \\
\hline 14:00 & 4,70 & 3,27 & 0 & 8 & 0,000 \\
\hline $14: 30$ & 3,40 & 2,78 & 0 & 60,60 & 0,000 \\
\hline 15:00 & 3,20 & 2,29 & 0 & 23,62 & 0,000 \\
\hline $15: 30$ & 1,21 & 1,95 & 0 & 8 & 0,000 \\
\hline 16:00 & 1,42 & 1,76 & 0 & 8 & 0,000 \\
\hline \multicolumn{6}{|c|}{ Data taken on June 20, 2021 - Day 2} \\
\hline 09:00 & 1,21 & 1,9 & 0 & 96,77 & 0,000 \\
\hline 09:30 & 1,44 & 1,81 & 0 & 115,38 & 0,000 \\
\hline 10:00 & 2,88 & 1,66 & 0 & 230,76 & 0,000 \\
\hline $10: 30$ & 1,60 & 1,56 & 0 & 127,65 & 0,000 \\
\hline 11:00 & 1,53 & 1,46 & 0 & 122,44 & 0,000 \\
\hline $11: 30$ & 1,50 & 1,37 & 0 & 120 & 0,000 \\
\hline 12:00 & 6,00 & 8,13 & 5,4 & 120 & 43,902 \\
\hline $12: 30$ & 4,95 & 5,69 & 0 & 115,38 & 0,000 \\
\hline 13:00 & 1,47 & 4,1 & 0 & 117,64 & 0,000 \\
\hline $13: 30$ & 4,90 & 3,34 & 0 & 111,11 & 0,000 \\
\hline $14: 00$ & 4,70 & 3,27 & 0 & 8 & 0,000 \\
\hline $14: 30$ & 3,40 & 2,78 & 0 & 60,60 & 0,000 \\
\hline 15:00 & 3,20 & 2,29 & 0 & 23,62 & 0,000 \\
\hline $15: 30$ & 1,21 & 1,95 & 0 & 8 & 0,000 \\
\hline 16:00 & 1,42 & 1,76 & 0 & 8 & 0,000 \\
\hline \multicolumn{6}{|c|}{ Data taken on June 21, 2021 - Day 3} \\
\hline 09:00 & 1,21 & 1,9 & 0 & 96,77 & 0,000 \\
\hline 09:30 & 1,44 & 1,81 & 0 & 115,38 & 0,000 \\
\hline 10:00 & 2,88 & 1,66 & 0 & 230,76 & 0,000 \\
\hline $10: 30$ & 1,60 & 1,56 & 0 & 127,65 & 0,000 \\
\hline 11:00 & 1,53 & 1,46 & 0 & 122,44 & 0,000 \\
\hline $11: 30$ & 1,50 & 1,37 & 0 & 120 & 0,000 \\
\hline $12: 00$ & 6,00 & 8,13 & 5,4 & 120 & 43,902 \\
\hline
\end{tabular}




\begin{tabular}{|c|c|c|c|c|c|}
\hline $12: 30$ & 4,95 & 5,69 & 0 & 115,38 & 0,000 \\
\hline $13: 00$ & 1,47 & 4,1 & 0 & 117,64 & 0,000 \\
\hline $13: 30$ & 4,90 & 3,34 & 0 & 111,11 & 0,000 \\
\hline $14: 00$ & 4,70 & 3,27 & 0 & 8 & 0,000 \\
\hline $14: 30$ & 3,40 & 2,78 & 0 & 60,60 & 0,000 \\
\hline $15: 00$ & 3,20 & 2,29 & 0 & 23,62 & 0,000 \\
\hline $15: 30$ & 1,21 & 1,95 & 0 & 8 & 0,000 \\
\hline $16: 00$ & 1,42 & 1,76 & 0 & 8 & 0,000 \\
\hline
\end{tabular}

From the data collection results as shown in Table 1, the data obtained is then processed and analyzed to produce a graph presented as shown in Figure 4 as follows.

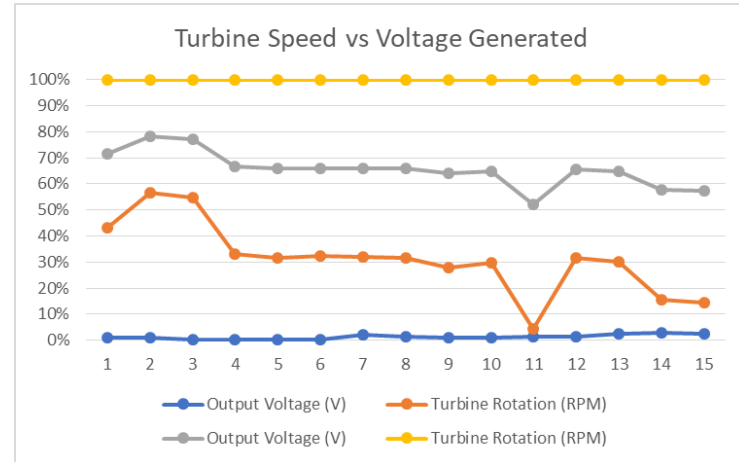

(a)

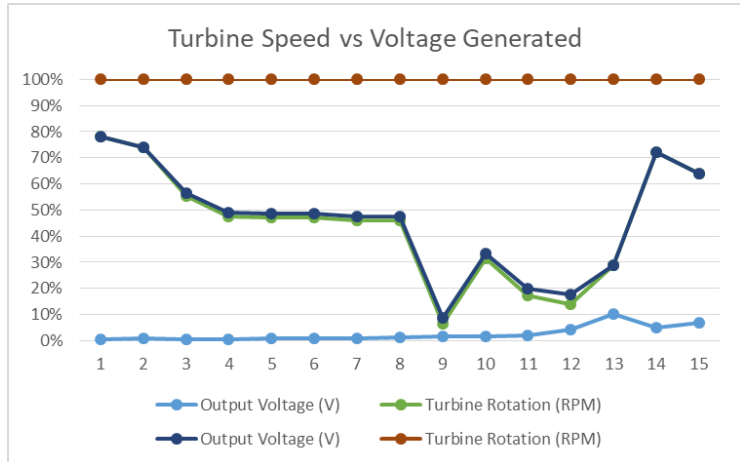

(b)

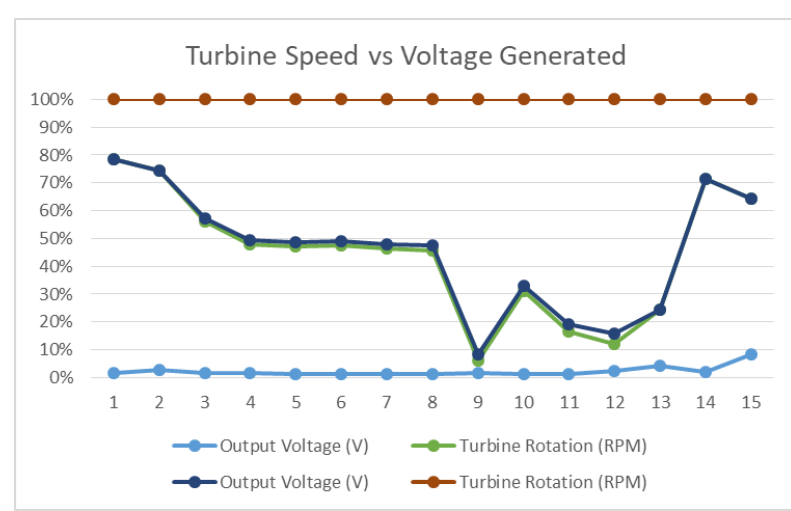

(C)

Figure 4. Comparison of 4 Blade and 5 Blade Turbine Speeds (Actual Conditions) vs Voltage generated from the turbine for 3 days, (a) Day 1 (b) Day 2 (c) Day 3

Turbine testing for three days proves that the resulting voltage affects the performance of the turbine rotation. It is seen that the difference in dimensions and the number of blades of the two types of turbines have an essential role in the design of the desired turbine design. Based on the graph presented in Figure 4 on the rotation of a four-blade wind turbine, it is known that the generated voltage influences the turbine rotation, the optimum condition can be seen when the turbine rotation is faster than the wind generator and produces a greater electrical voltage is supported by sufficient wind speed.

\section{CONCLUSION}

In the research analysis of the performance of the four-blade darrieus wind turbine at the Jamik Bukit Asam Mosque Complex, Tanjung Enim, South Sumatra, it is known that the results of the four-blade 
turbine performance for Coffee Shop electricity needs that the wind turbine, wind turbine rotation, the value of the output voltage and the current generated significantly affect wind speed in the area.

\section{ACKNOWLEDGEMENTS}

Authors would like to express deeply gratitude to PT Bukit Asam Tbk for providing the research location and supporting this research.

\section{REFERENCES}

[1] Wardhana. Agum Try, Taqwa. Ahmad, Dewi. Tresna, "Design of Mini Horizontal Wind Turbine for Low Wind Speed Area," IOP Conf. Series: Journal of Physics: Conf. Series 1167 (2019) 012022.

[2] A. Taqwa, "Higher Education Role in Supporting Indonesian Government Policy in Developing Renewable Energy,” J. Phys.: Conf. Ser. 1167 012010, 2019.

[3] W. Sando Krisna, "Effect of Blade Number on H Terhadap-Type Darrieus Wind Turbine Performance," SimkiTechsain Vol. 01 No. 05, 2017.

[4] R. Ploetz, Rusdianasari, Eviliana, "Renewable Energy: Advantages and Disadvantages. Proceeding Forum in Research, Science, and Technology (FIRST), 2016.

[5] DESDM, "National Energy Management Blueprint 2005-2025 (PDF File)," Available from http://psdg.bgl.esdm.go.id, 2005.

[6] R.B. Yuliandi, Rusdianasari, T. Dewi, "Comparison of Blade Dimension Design of a Vertical Wind Turbine Applied in Low Wind Speed," E3S Web of Conferences. 1st SRICOENV, 2018.

[7] Mojola O.O. J, "Wind Eng Ind Aerod 21,” (1985).

[8] C. Sovannara, Firdaus, Rusdianasari, "A Review on Environmental Impact of Wind Energy," Proceeding Forum in Research, Science, and Technology (FIRST), 2016.

[9] A. Garmana, F. Arifin, Rusdianasari, "CFD Analysis for Combination Darrieus and Savonius Turbine with Differences in the Number of Savonius Turbine Blades," International Conference on Artificial Intelligence and Mechatronics Systems (AIMS), 2021.

[10] A. Susandi, F. Arifin, RD. Kusumanto, "Simulation of Diffuser Parameters in the Performance of Horizontal Axis Wind Turbine using Computational Fluid Dynamics," Technology Reports of Kansai University. Volume 63, Issue 06, June, 2021.

[11] A. Taqwa, R. Rusdianasari, Budiman, RD. Kusumanto, T. Dewi, "Synchronization and application of IoT for on grid hybrid PV-wind system," International Conference on Applied Science and Technology (iCAST) IEEE 617$621,2018$.

[12] Data Center and Information Technology, "Forecast of Energy Supply and Utilization of Regional EBT Optimization Scenario," Ministry of Energy and Mineral Resources, 2016.

[13] N. Pasaribu, Rusdianasari, and A. Syarif, "Efficiency of 9Kwp Sun Tracking Photovoltaic in Palembang, Indonesia", IOP Conf. Ser.: Earth Environ. Sci. 347 012129, 2019.

[14] H. Wibowo, Y. Bow, and CR. Sitompul, "Performance Comparison Analysis of Fixed and Solar-Tracker Installed Panel at PV System”, IOP Conf. Ser.: Earth Environ. Sci. 709 012003, 2021.

[15] Institute for Essential Service Reform, "Buletin Strategic Partnership Green and Inclusive Energy," Jakarta, November 2019.

[16] A. Kurniawan, A. Taqwa, Y. Bow, "PLC Application as an Automatic Transfer Switch for on-grid PV System; Case Study Jakabaring Solar Power Plant Palembang,” J. Phys.: Conf. Ser. 1167 012026, 2019.

[17] S Widodo, A Taqwa and R Rusdianasari, "Solar panels output optimization using Phase Change Material (PCM) and heatsink applied in open-pit mining," IOP Conf. Series: Materials Science and Engineering 1073 (2021) 012041, 2021.

[18] Mirdiansyah, A. Taqwa, Y. Bow. "Monitoring Depth of Discharge of a Valve Regulated Lead Acid Battery in a Standalone PV System," Proceedings of the 4th Forum in Research, Science, and Technology (FIRST-T1-T22020), 2021

[19] M. Kalantar, S. M. Mousavi, "Dynamic behavior of a stand-alone hybrid power generation system of wind turbine, microturbine," solar array and battery storage. Appl Energy 2010;87:3051-64.

[20] Y. Bow, A. Syakdani, M. Taufik, and Rusdianasari, "Effect of Drying Ariflow Rate on $\mathrm{H}_{2} \mathrm{O}$ Mass Evaporated on Banana Chips Drying using Photovoltaic Solar Panel”, J. Phys.: Conf. Ser. 1500 012015, 2020.

[21] Rusdianasari, Y Bow, RAN Moulita. Temperature Effect on the Biodiesel Quality from Waste Cooking Oil by Induction Heating, Journal of Physics: Conf. Series 1450 012003. 2020.

[22] Rusdianasari, A Syarif, M Yerizam, MS Yusi, L Kalsum, Y Bow. Effect of Catalyst on the Quality of Biodiesel from Waste Cooking oil by Induction Heating, Journal of Physics: Conf. Series 1500 (012052). 2020.

[23] RAN Moulita, Rusdianasari, and L. Kalsum, Converting Waste Cooking Oil into Biodiesel using Microwaves and High Voltage Technology, J. Phys: Conf.Ser. 1167 012033, 2019.

[24] S. Yunsari, Rusdianasari, and A. Husaini, CPO Based Biodiesel Production using Microwaves Assisted Method, J. Phys. Conf. Ser., vol. 1167, no. 1, 2019.

[25] S Susumu, R Rusdianasari, S Yusi. Biodiesel Production from Waste Cooking Oil using Electrostatic Method, Indonesia Journal of Fundamental and Applied Chemistry (IJFAC) 3(3). 2020. 


\section{BIOGRAPHIES OF AUTHORS}

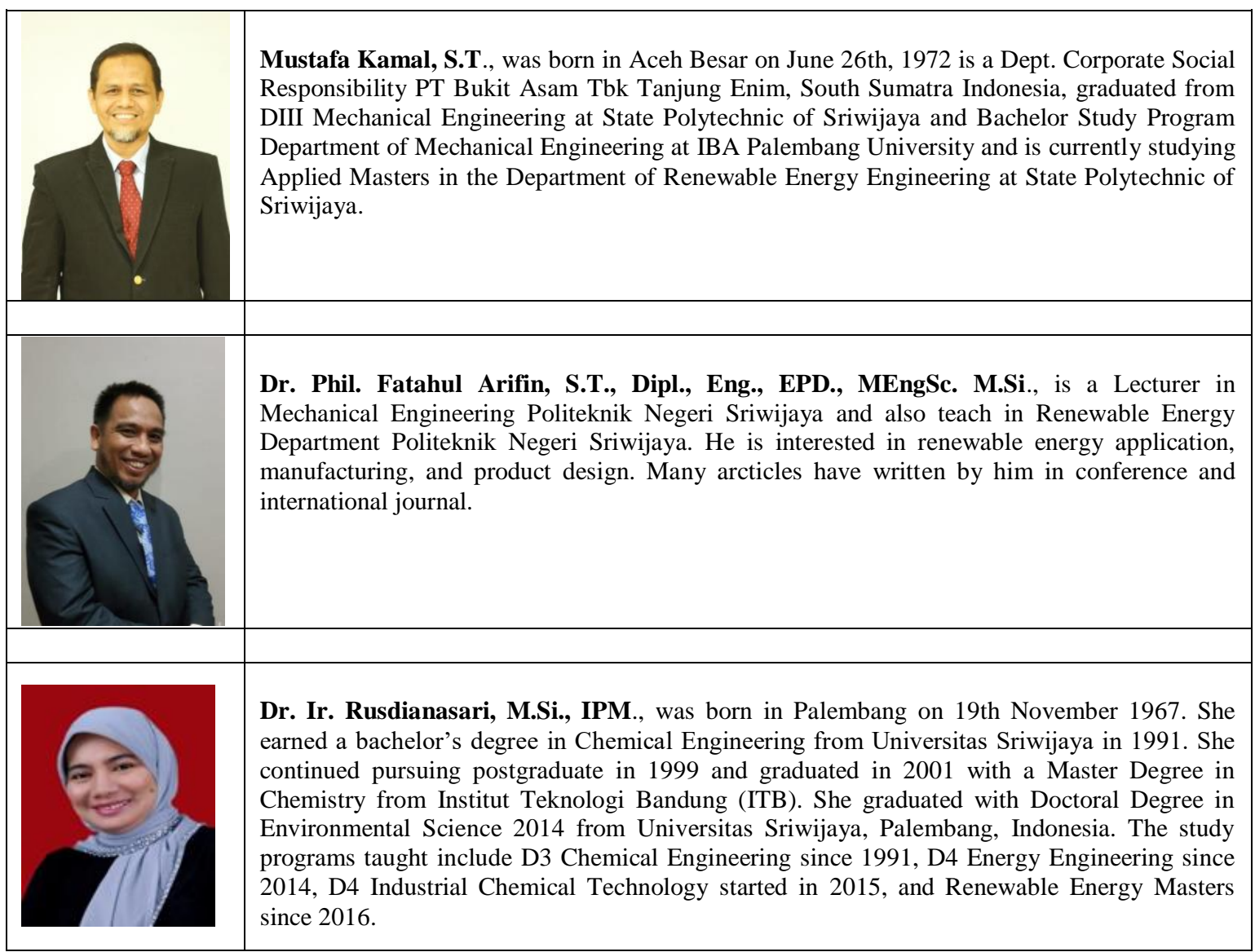

